NBER WORKING PAPER SERIES

SOCIAL SECURITY AND EARLIER

RETIREMENT IN JAPAN:

CROSS-SECTIONAL EVIDENCE

Tetsuji Yamada

Tadashi Yamada

Working Paper No. 2442

NATIONAL BUREAU OF ECONOMIC RESEARCH

1050 Massachusetts Avenue

Cambridge, MA 02138

November 1987

The research reported here is part of the NBER's research program in Health Economics. Any opinions expressed are those of the authors and not those of the Nationa? Bureau of Economic Research. 


\title{
Social Security and Earlier Retirement in Japan: Cross-Sectional Evidence
}

\begin{abstract}
The estimated elasticity of the probability of retirement with respect to social security retirement benefits declines as individuals age. The negative impact of social security retirement benefits on full-time workers is much greater than the impact on part-time workers for all age groups. Earnings test in Japan is, therefore, more effective on full-time workers than part-tine workers among the elderly. Social security retirement benefits also provide the elderly with an incentive to prolong their unemployment status. The marginal effect of the market unemployment rate on full-time work is significantly larger than that on part-tine work and both effects are negative. The elasticity of retirement with respect to the market unemployment rate for those in their $60^{\prime} \mathrm{s}$ is two to three times larger than those aged 70 and over. Retirement of those in their 60's is quite responsive to changes in labor market condition.
\end{abstract}

Tetsujj Yamada Department of Economics Rutgers University - Camden The state University of New Jersey Camden, N.J. 08102
Tadashi Yamada

NBER

269 Mercer Street

8th Floor

New York, N.Y. 10003 
Social Security and Earlier Retirenent in Japan:

Cross-Sectional Evidence

Tetsuji Yamada and Tadashi Yamada*

\section{Introduction}

At the request of Japanese government, Japanese firms have recently begun to increase mandatory retirement ages beyond the traditional age of fifty-five, ${ }^{1}$ Japanese business firms and other institutions are required by law to have 6.9 percent of their total employnent to be comprised of individuals, 55 and over. ${ }^{2}$

As Japan is becoming an "aging society", a more comprehensive social security retirement systen is necessary. The provision of such a systen alleviates the financial problems of the elderly and is likely to encourage elderly workers to leave the labor market earlier, possibly inposing a relatively higher tax burden on working generations. Yet job vacancies due to the earlier retirement of the elderly may provide job opportunities for younger working generations.

Despite its social-and-economic-policy importance in Japan, few theoretical and empirical studies have explored the effects of social security retirement benefits on the retirement behavior of elderiy male workers, with the exception of the recent studies by Takayana (1982) and Ito (1983). However, these two studies do not specifically focus on the relationship between social security retirement benefits and the retirement decisions of the elderly in an econometric multivariate analysis. Consequently, the quantitative impact of the social-security-retirement-benefit effect on the retirement decisions is not well documented. ${ }^{3}$

The purpose of this study is to analyze the retirement decisions of ejderjy maje workers in the context of multivariate analysis. We hypothesize 
that the responses of retirement decisions to socio-economic factors differ by age. We consider the age groups $60-64,65-69$, and 70 and over. By further separating each age group according to their degree of labor attachment, e.g., full-time work, part-time work, unemployment, and retirement, we examine the transitional aspects of the retirement decisions of elderly male workers. This sort of application should not be underestimated for two reasons: first, understanding the effect of social security retirement benefits on the retirement decisions of the elderly is valuable and crucial in determining social and economic policy. Secondly, an evaluation of the quantitative effects rests on empirical studies such as ours.

The organization of the subsequent sections is as follows. Section II contains a brief review of the Welfare Pension in Japan. In Section III we describe our theoretical model. We present the the enpirical results in section IV and state our conclusions in section $V$. 


\section{A Brief Review of the Welfare Pension}

In Japan, the social security program (Welfare Pension) was introduced in 1942. The Welfare Pension covering a majority of Japanese workers is a partially funded system, not a pay-as-you-go system. ${ }^{4}$ Under the Welfare Pension a flat tax rate of $10.6 \%$ is applied to monthly labor earnings up to a maximum of 410 thousand yen from a minimum of 45 thousand yen for male workers. The rate is $8.9 \%$ for female workers. ${ }^{5}$ Half of the social security tax rate is paid by the employer, as is true with the U.S. social security system.

Retirement benefits of the Japanese Welfare Pension (social security retirement benefits, SSRB) are indexed to the inflation rate and generally require 20 year minimum contributions. The normal retirement age is 60 for men and 55 for women. ${ }^{6}$ The basic schedule of monthly social security retirement benefits for a typical indivjdual " $j$ " is given as follows (Japan. White Paper of Welfare 1983): ${ }^{7}$

$$
\begin{aligned}
\mathrm{SSRB}_{\mathrm{i}}= & 2,050_{\text {yen }} \times \mathrm{T}\left\{\mathrm{T}=20 \text { if } \mathrm{T}_{\mathrm{i}} \leq 20 ; \mathrm{T}=\mathrm{T}_{\mathrm{i}} \text { if } 20<\mathrm{T}_{\mathrm{i}}<35 ;\right. \\
& \text { and } \left.\mathrm{T}=35 \text { if } \mathrm{T}_{\mathrm{i}} \geq 35\right\}+\left[\left(\Sigma_{\mathrm{t}=1}^{12 \mathrm{Ti}} \mathrm{W}_{\mathrm{it}} / 12 \mathrm{~T}_{\mathrm{i}}\right)\right. \\
& \left.\times(1 / 100) \times \mathrm{T}_{\mathrm{i}}\right], \ldots \ldots \text { (1) }
\end{aligned}
$$

where $\mathrm{T}_{i}=$ number of preretirement working years, and $w_{i, t}=$ monthly labor earnings in time $t$. The payment of monthly social security retirement benefits is reduced according to the amount of an individual's monthly labor earnings as shown in Table 1 . Table 1 provides the schedule of the payments.

[Table 1 should be here]

As we note from the above schedule, the current system of social security retirement benefits in Japan has only an income effect. for the elderly in the age categories of $60-64$ and 65 and over. In Figure 1, we have drawn illustrative monthly budget constraints for the elderly in both age groups.

[Figure 1 should be here]

The distance $O A$ indicates the amount of monthly social security retirement 
benefits, assuming no other non-labor income, for individuals working zero hours a month (the benefits and wage rates are assumed to be the same for both age groups). The saw shaped budget line ABFGHIJ is the schedule for the elderly in the 60-64 age category, whereas the budget line ABCDE is for those in the 65 and over age category.

Noting that the income level at F (in Figure 1) is more than that at G and $H$, the elderly in the 60-64 age category are likely to work either relatively few hours (less than or equal to $\mathrm{T}_{1}$ hours or $\mathrm{T}_{2}$ hours) a month while receiving at least eighty percent of their social security retirement benefits or a substantially larger number of hours (more than $\mathrm{T}_{4}$ hours) with zero social security retirement benefits. ${ }^{8}$ This budget constraint results from a lump-sum reduction in social security retirement benefits according to their labor earnings, rather than a proportional reduction of labor earnings from social security retirement benefits as with the United States social security system.

On the other hand, the elderly in the age category of 65 and over face a minimal social security retirement benefits reduction. The reduction is only 20 percent of the benefits when their labor earnings exceed 150 thousand yen. That is, in the transition from the 60-64 age group to another age group of 65 and over the elderly will experience a strong income effect from social security retirement benefits (i.e., from budget constraint $A B F G H I$ to $A B C D E$ in Figure 1), resulting in a reduction either in their working hours or their labor force participation.

In this study, we focus on the labor force participation of three different age groups of elderly men: ages 60-64, 65-69, and 70 and over. Furthermore, among each age group we separate the degree of labor involvement by classifying full-time work, part-time work, unemployment, and retirement. An advantage of using the labor force participation rates of the elderly and 
classifying each by labor attachment is that we are able to examine the transitional aspects of their labor retirement decisions. 
III. Empirical Model and Theoretical Arguments

The percentage of full-time male workers among the total number of elderly male workers diminishes with age as follows: 85.0 percent among those aged 55 to $59,71.0$ percent among those aged 60 to 64 , and 61.0 percent among those aged 65 to 69 , in 1980 (White Paper of Labor, 1983). ${ }^{9}$ On the other hand, the corresponding percentages of part-time workers rises with age, 14.7 percent, 28.7 percent, and 38.7 percent for those aged 55 to 59,60 to 64 , and 65 to 69 , respectively. These rates illustrate the transitional aspect of working decisions. A similar pattern is also observed in U.S. studies (Gustman and Steinmeier 1983 and 1984; Honig and Hanock 1985). Thus, we separate full-time work, part-time work, unemployment, and retirement for each of the three age groups : $60-64,65-69$, and 70 and over. ${ }^{10}$

The variables in our model are cross-sectional market averages primarily drawn from the 1980 Population Census of Japan. ${ }^{11}$ Our approach assumes that a typical elderly man faces four mutually exclusive alternatives with the corresponding probabilities $\mathrm{P}_{1}, \mathrm{P}_{2}, \mathrm{P}_{3}$, and $\mathrm{P}_{4}$, which represent the probabilities that the man chooses full-time work, part-time work, unemployment, or retirement, respectively. By definition, the sum of the probabilities is equal to one. The logistic probability function is:

$$
\text { (1) } \begin{aligned}
P_{i} & =\left[\exp \left(a_{i}+\Sigma_{j}\left(B_{i j} X_{i}\right)\right) /\left(1+\Sigma_{i} \exp \left(a_{j}+\Sigma_{j}\left(B_{i j} X_{j}\right)\right)\right)\right], \\
i & =1,2, \text { and } 3
\end{aligned}
$$

and :

(2) $P_{4}=\left[1 /\left(1+\Sigma_{i} \exp \left(a_{i}+\Sigma_{j}\left(B_{i j} x_{j}\right)\right)\right)\right]$,

where the $x_{j}, j=1, \ldots, m$, are the independent variables.

By solving for the log-odds ratio of the $i^{\text {th }}$ type of participation decision $\left(P_{i}\right.$ relative to $\left.P_{4}\right)$, the logistic equation can be expressed in the linear form: 
(3) $\quad \ln \left(P_{i} / P_{4}\right)=a_{i}+\Sigma_{j}\left(B_{i j} X_{j}\right), \quad i=1,2$, and 3 .

The marginal effect of $X_{j}$ on $P_{i}$ is obtained from:

$$
\left(\delta P_{i} / \delta X_{j}\right)=B_{i j} P_{i}-P_{i} \Sigma_{i}\left(B_{i j} P_{i}\right), i=1,2 \text {, and } 3 \text {. }
$$

and:

$$
\left(\delta \mathrm{P}_{4} / \delta \mathrm{X}_{j}\right)=-\Sigma_{i}\left(\delta \mathrm{P}_{i} / \delta \mathrm{X}_{j}\right)
$$

In our model, the $P_{i}$ are unobserved and constrained to the interval from zero to one. For the estimation of equation (3), we substitute $P_{f}$ (the proportion of elderly men in a given age group who are full-time participants in the labor market) for $\mathrm{P}_{1} ; \mathrm{P}_{\mathrm{p}}$ (the proportion of those men who are part-time participants) for $\mathrm{P}_{2}$; $\mathrm{P}_{\mathrm{u}}$ (the proportion of unemployed elderly men in the age group) for $\mathrm{P}_{3} ;$ and $\mathrm{P}_{\mathrm{r}}$ (the proportion of those men who are retired) for $\mathrm{P}_{4}$. Each equation will be estimated using generalized least squares so as to correct for heteroscedasticity. The weights to be used are given by:

(6) $\mathrm{w}_{i}=\left[\text { (total male population in a given age group) } \mathrm{P}_{i} \mathrm{P}_{\mathrm{r}}\right]^{\frac{1}{2}}, i=f, p$, and $u$.

This study employs the following explanatory variables: social security retirement benefits, full-time male wages, part-time male wages, unemployment, family wealth, education, presence of spouse, family structure, and health condition. The variables are defined in Table 2 and their statistics are reported in Table 3 . We briefly discuss the explanatory variables of interest.

[Tables 2 and 3 should be here]

The availability of social security retirement benefits (SSRB) will discourage the labor force participation of the elderly due to its income effect, as discussed in section II, ${ }^{12}$ An increase in either full-time or parttime wages is likely to influence the elderly to substitute between full-time and part-time work, after considering the effect on social security retirement benefits. We use two proxy variables for family wealth: the sum of income flows from assets such as housing, land, stocks, and bonds; and personal savings. Their effects on the retirement decisions of the elderly will be 
different because their liquidity differs

Elderly men, with spouse present, are likely to be integrated into their communities as workers and/or to have financial responsibility. We expect the presence of a spouse to a positive effect on labor force participation. The family structure variable is the proportion of elderly living with their children and grandchildren. Elderly living with their children and grandchildren seem to have income effect against labor force participation due to other members' earnings. Finally, the health condition of the elderly cannot be ignored. Health improvement positively affects their work efforts (Rones 1980; Fuchs 1984). Noise, population density and heavy traffic may cause tension to rise and consequently to have an adverse effect on an individual's health condition (Gerking and Schulze 1981; Cropper 1981). Lifestyle health habits, e.g., cigarette smoking and diet, will also influence health quality (Rosen 1981; Wolfe 1984). 


\section{Empirical Results}

Tables 4,5 , and 6 present the results obtained from our estimation model for three age groups: $60-64,65-69$, and 70 and over, respectively.

[Tables 4,5 and 6 should be here]

One notable finding is that the estimated coefficients on the social security retirement benefits variable (SSRB) are statistically significant and negative in the full-time and part-time equations for all age groups. The estimated elasticity of the probability of retirement with respect to social security retirement benefits, evaluated at the sample means, is 1.29 for elderly men in the 60-64 age category. ${ }^{13}$ The retirement elasticities for the elderly in the age categories of $65-69$ and 70 and over are .57 and .08, respectively. An increase in social security retirement benefits induces earlier retirement of elderly men.

The declining elasticity of retirement with respect to social security retirement benefits with age is composed of the following factors:

(1) the proportion of retirement (R) rises from .211 (60-64), to .377 (65$69)$ and .675 (70 and over) as ages advance;

(2) the ratio of full-time work to retirement (F/R) decreases from 3.35 (60-64) to $1.29(65-69)$, and .34 (70 and over); and

(3) the full-time elasticities with respect to social security retirement benefits $(\delta \operatorname{lnF} / \delta \operatorname{lnSSRB})$ are $-.40(60-64),-.39(65-69)$, and -.19 (70 and over). A one percent increase in social security retirement benefits will lead to a .4 percent decrease in full-time labor force participation among the age groups 60-64 and 65-69, and a 19 percent reduction among the age group of 70 and over.

In comparison to the elasticity of full-time work with respect to social security retirement benefits, the part-time elasticity is much smaller and invariant with age: $-.01(60-64),-.02(65-69),-.01$ (70 and over). These 
results indicate that the earnings test in Japan is more effective on fulltime workers than part-time workers among the elderly. ${ }^{14}$

The positive effect of social security retirement benefits on unemployment for all age groups (column 3 in Tables 4,5 and 6 ) show that the eligibility for both unemployment insurance benefits and social security retirement benefits provides the elderly with an incentive to prolong their unemployment status and, hence, the unemployed elderly maximize their entitled benefits. ${ }^{15}$ This finding is congruent with the report of Ito (1983).

Another noteworthy finding is that retirement among the elderly is a consequence of their difficulty of finding jobs in Japan. In Tables 4,5 and 6, the effects of the market unemployment rate on full-time work and part-time work are significantly negative for all age groups. A decrease in the probability of labor force participation in full-time work and part-time work due to an increase in the unemployment rate represents the discouragement effect. The marginal effects of the market unemployment rate on full-time work are much greater than those on part-time work for all age groups. ${ }^{16}$ A one percentage point increase in the unemployment rate reduces full-time-work labor force participation by 4.1 percentage points $(60-64), 4.0$ percentage points (65-69), and 3.0 percentage points (70 and over). The reductions in the labor force participation rates for part-time work are .01 percentage points $(60-64), .08$ percentage points (65-69), and .02 percentage points (70 and over).

The elasticity of retirement with respect to the market unemployment rate (the discouragement effect) is .40 (60-64),.26 (65-69), and .12 (70 and over) at the sample means. In comparison with the estimated elasticity of retirement with respect to social security retirement benefits (the induced retirement effect) of $1.29(60-64), .57(65-69)$, and .08 (70 and over), the induced retirement effect is larger in magnitude than the discouragement effect, except for the elderly in the 70 and over age category. Yet, the statistically 
significant discouragement effect indicates that the elderly face the dilemma of discouragement from searching unsuccessfully for jobs and the consequent stigma of unemployment. Dwindling job opportunities for the elderly during a period of high market unemployment persuade them to exit the job market.

The estimated coefficients on the presence of a spouse variable in the full-time work equation are statistically significant and poitive for all age groups. Financial responsibility for the spouse is likely one of the reasons. With respect to family structure, the elderly living with their children and grandchildren tend to reduce their full-time work activity. However, the positive effect on part-time work among all age groups suggests that the family structure does not necessarily force the elderly to leave the labor market completely, but lets them stay at the intermediate state as part-time workers before retirement.

To represent health conditions, we included tension and life expectancy variables. The former is measured by public nuisance complaints (noise pollution) received by local public bodies. For the latter, the predicted value of life expectancy is used: the instrumental variables are medical care, daily diet of salty paste, cigarette smoking, nutrition guidance, education, inspective facilities of food and enviroment sanitation, and air pollution. The tension variable has negative effects on full-time work, part-time work and unemployment for all age groups. That is, a rise in tenision reduces the work effort of the elderly, shortens their labor market activities and consequently compels the elderly to withdraw from the labor market, namely to rtire. The effects of the life expectancy variables are weak, though some of them are statistically significant and positive. 


\section{Conclusion}

The Japanese Goverment recently requested private firms and public organizations to extend mandatory retirement ages beyond the traditional age of fifty-five. To implement proper socioeconomic and health-related policy action, we consider it indispensable to understand the underlying factors influencing the retirement decisions of the elderly. We examined the effect of social security retirement benefits on the retirement decisions of elderly male workers in different age groups $(60-64,65-64$, and 70 and over) with full-time work, part-time work, unemployment, and retirement separately studied for each. The variables in our model are cross-sectional market averages primarily drawn from the 1980 Population Census of Japan.

The major findings in this study are that retirement decisions are mainly determined by social security retirement benefits and the market unemployment rate. An increase in social security retirement benefits induces the elderly to leave the labor market when they become eligible for the benefits (i.e, the induced retirement effect). Retirement among the elderly is also a consequence of their difficulty in finding jobs (i.e, the discouragement effect). The induced retirement effect dominates the discouragement effect.

The estimated elasticity of the probability of retirement with respect to social security retirement benefits declines as ages advance. The negative impact of social security retirement benefits on full-time workers is much greater than on part-time workers for all age groups. Earnings test in Japan is, therefore, more effective on full-time workers than part-time workers among the elderly. Social securjty retirement benefits also provide the elderly with an incentive to prolong their unemploymed status. The marginal effect of the market unemployment rate on full-time work is significantly larger than that on part-time work and both effects are negative. The elas- 
ticity of retirement with respect to the market unemployment rate for those in their 60's is two to three times larger than for those ages 70 and over. Retirement of those in their $60 \mathrm{~s}$ is also quite responsive to changes in labor market conditions.

Among the other variables in our model, we found that elderly men with a spouse are strongly attached to the full-time labor market, indicating their integration into communities and financial responsibility. When living with their children and grandchildren, the elderly tend to reduce their full-time work activity but stay at the intermediate state, working part time before complete retirement.

As a concluding remark, the retirenent of the elderly is attributable mainly to social security retirement benefits and dwindling job opportunities. To advance the understanding of socioeconomic activities of the elderly, more studies of this type are encouraged in Japan. 
FOOTNOTES

*We are indebted to Michael Grossman, Koichi Hamada, Marjorie Honig, Robert A. Moffitt and Bernard Okun for their helpful comments on preliminary drafts of this paper. The opinions expressed in this paper, as well as any errors, are ours.

1. In 1980 , the business firms, which set the mandatory retirement ages at 55 or less, accounted for 39.7 percent of the total business firms. Those with retirement ages between 56 and 59 years old accounted for 20.1 percent while those with ages 60 or over accounted for 39.7 percent. These proportions in 1982 became 35.5 percent, 18.2 percent, and 56.9 percent, respectively (White Paper of Labor, Showa 58 Nenban (1983), pp. $66-70$ ).

2. Under the law the ratio of the elderly workers was gradually raised from 5.8 percent in 1979 to 6.2 percent in $1980,6.6$ percent in 1981 , and 6.9 percent in 1982 (White Paper of Labor, Showa 58 Nenban (1983), p. 69).

3. In the United States, the social security system seems to create a trend toward earlier retirement, though some studies negate the earlier retirement effects. Boskin (1977), Pellechio (1979), Hurd and Boskin (1984), and Mitchell and Fields (1984) suggest that social security retirement benefits exert a significant influence on the retirement decision and induce earlier retirement. Blinder, Gordon and Wise (1980), and Hanmermesh (1984), however, find that social security retirement benefits do not present a work disincentive to the elderly under age 65 but rather that the elderly stay longer in the labor market becasue of an increase in deferred retirement benefits .

4. Another social security retirement program is the National Pension for self-employed workers and housewives who are not employed. Private pensions are still at an early stage in Japan and the data are not available. 
5. After April in 1986, the rates were raised to 12.4 percent and 11.3 percent for male and female workers, respectively.

6. After April in 1986, the normal retirement age for female workers was raised to sixty years old with gradual adjustments.

7. A typical retired male with zero working hours a month, received 136 thousand yen (SSRB) per month in 1983, based on the condition that he, with spouse present, had worked for 30 years. The replacement rate, proxied by the ratio of social security retirement benefits to personal disposable income per capita in real terms, was about 50 percent on the average over the period from 1970 to 1982 . This rate is low in comparison to the U.S. standard (Aldrich 1982).

8. According to the Wage Census 1983, a typical male aged between 60 and 64 earned 1,290 yen per hour on at the average full-time job. In Table 1, if a typical male worker receives labor earnings more than 92 thousand yen but less than 150 thousand yen a month, his total income (social security retirement benefits plus his labor earnings) is often smaller than the case in which he earns labor earnings between 45 thousand and 92 thousand yen. The fact is that the labor earnings of more than 92 thousand yen but less than 150 thousand yen result in a 50 or an 80 percent reduction in social security retirement benefits, while the other income range results in only a 20 percent reduction. Therefore, it is clear that choosing working hours in the labor income range of than 92 thousand yen but less than 150 thousand yen is an inferior solution to maximize total income.

9. The proportion of the elderly in the age category of 70 and over is not reported.

10. According to the 1980 Population Census of Japan (pp. XI-XXI), "employed" persons refer to all persons who did any work during the week prior to the census date for pay or profit, such as wages, salary, allowance, busi- 
ness profit, etc., as well as persons who had a job or business but did not work at all during the week prior to the census date because of vacation, illness, bad weather, labor dispute, or personal reasons. Unemployed persons refer to those who had no job but were able to work and were actively seeking a job during the week prior to the census date. Among employed elderly men, the two major categories in the Census are "mainly working or mostly worked" and "secondarily working or working besides doing housework". There are, however, no classifications for employed elderly men in terms of working hours or weeks. Therefore, full-time work and part-time work in this paper refer to "mainly working or mostly worked" and "secondarily working or working besides doing housework" in the Census, respectively.

11. Japan is administratively divided into forty-seven prefectures, of which one carries the suffix "To", one carries "Do", two carry "Fu", and forty-three carry "Ken". Each prefecture is further subdivided into "Shi(city)" and "Gun(rural county)". "Gun" are further subdivided into "Cho(town)" and "Mura(village)". In our study, we employ data for urban areas, referred to as "Shi(cities)". Further insight into the retirement decisions of Japanese elderly men awaits the availability of individual and logitudinal data, which, we find after conversations with Professor Yoshio Higuchi, are inaccessible to reseachers not affiliated with the Japanese Government.

12. In the studies on the United States, Burtless and Moffitt (1985), Duggan (1984), Hanoch and Honig (1983), Honig and Hanoch (1985), Hurd and Boskin (1984), and Mitchell and Fields (1984) find social security retirement benefits to induce earlier retirement.

13. The retirement elasticity is obtained from the following formula: $(d \ln R / d \ln S S R B)=-[(F / R)(\delta \ln F / \delta \operatorname{lnSSRB})+(P / R)(\delta \ln P / \delta \operatorname{lnSSRB})+$

$$
(U / R)(\delta \ln U / \delta \ln S S R B)] \text {, }
$$

where $R, F, P$, and $U$ of the elderly in a given age category are 
average proportions of retirement, full-time work, part-time work, and unemployment, respectively, and $R+F+P+U=1$.

14. There are little qualitative and quantitative changes, when social security retirement benefits are treated endogenous and the predicted values are used in the model.

15. The stated period of unemployment insurance benefits is 300 days and, in addition, an extension is allowed from 60 to a maximum of 90 days under certain conditions. The unemployment benefits are not subject to the reduction of social security retirement benefits.

16. The marginal effect is obtained from the application of equation (4). 
Table 1

Monthly Social Security Retirement Benefits in Yen (as of 1985)

$\begin{array}{ll}60-64 & \text { Monthly SSRB } \\ 45,000<w_{i} \leq 92,000 & 0.8 \times \text { SSRB } \\ 92,000<w_{i} \leq 126,000 & 0.5 \times \text { SSRB } \\ 126,000<w_{i} \leq 150,000 & 0.2 \times \text { SSRB } \\ 150,000<w_{i} & 0 \times \text { SSRB } \\ 65 \text { and }+\quad W_{i} \leq 150,000 & 1 \times \text { SSRB (full amount) } \\ 150,000<w_{i} & 0.8 \times \text { SSRB }\end{array}$

Source: Social Insurance Handbook 1983 (1982).

Note. Wi is individual monthly lahor earnings, which inclute wages and payments in kind. Bonuses are also included if they are given four times or more a year. Total benefits are social security retirement benefits (SSRB) plus 15,000 x $F\{F=1$ if spouse is alive; and $\mathrm{F}=0$ otherwise $\}+5,000$ yen $\mathrm{x}\left\{\mathrm{Nen}=\mathrm{min}\left(\mathrm{N}_{1}, 2\right)\right\}+$ 2,000 yen $\times\left(N_{i}-2\right)\left\langle\right.$ if $N_{i}>3, N_{i}=2$ otherwise\}, where $N_{i}$ is the number of dependent children. 
Table 2

Definitions of Variables

SSRB -- The average of annual social security retirement benefits for a retired person, in one thousand yen deflated by the cost of living in 1980, for all age groups.

Full-time male worker (Pf) -- The proportion of full-time male workers aged 60-64,65-69, and 70 and over in cities in 1980 for age groups 60-64, 65-69, and 70 and over respectively.

Part-time male worker (Pp) -- The proportion of part-time male workers aged 60-64,65-69, and 70 and over in cities in 1980 for age groups 60-64, 65-69, and 70 and over respectively.

Unemployed (Pu) -- The proportion of unemployed males aged 60-64, 65-69, and 70 and over in cities in 1980 for age groups 60-64, 65-69, and 70 and over respectively.

Retired (Pr) -- The proportion of retired males aged 60-64, 65-69, and 70 and over in cities in 1980 for age groups 60-64, 65-69, and 70 and over respectively.

Full-time male wage -- Hourly full-time male wage aged 60-64, in one thousand yen deflated by the cost of living in 1980, for age group 60-64. Hourly full-time male wage aged 65 and over, in one thousand yen deflated by the cost of living in 1980, is used for age groups 65-69, and 70 and over.

Part-time male wage -- Hourly part-time male wage aged 60-64, in one thousand yen deflated by the cost of living in 1980 for age group 60-64. Hourly part-time male wage aged 65 and over, in one thousand yen deflated by the cost of living in 1980, is used for age groups 65-69, and 70 and over.

Market Unemployment -- The proportion of the total labor force aged 15 and over who are unemployed, in cities in 1980 for all age groups.

Non-labor income -- Income from rent, dividends, and interest from bonds, per person in houshold sector in one thousand yen deflated by the cost of living in 1980 for all age groups.

Personal savings -- The balance of personal savings per person in one thousand yen deflated by the cost of living in 1980 for all age groups.

(continued) 
Table 2 (concluded)

Definitions of Variables

Education -- The proportion of males aged 60-64 with at least a senior high school education in cities in 1980 for age group 60-64. The proportion of males aged 65 and over with at least a senior high school education in 1980 is used for age groups 65-69, and 70 and over.

Presence of spouse -- The proportion of males aged 60-64,65-69, and 70 and over living with wife, in cities, in 1980, for age groups 60-64, 65-69, and 70 and over respectively.

Family structure -- The proportion of elderly living with two or three generations together, in cities, in 1980.

Tension -- The percentage change in complaints received by local public bodies for public nuisances (noise pollution), in 1980.

Life expectancy -- Predicted life expectancy as a proxy measure of health quality. 
Table 3

Statistics

Weighted Means and Standard Deviations

\begin{tabular}{|c|c|c|c|}
\hline Variable & $\begin{array}{l}\text { Me } \\
\text { (Standard } \\
\text { age group } \\
60-64\end{array}$ & $\begin{array}{l}\text { Deviations) } \\
\text { age group } \\
65-69\end{array}$ & $\begin{array}{l}\text { age group } \\
70 \text { and over }\end{array}$ \\
\hline SSRB & $\begin{array}{r}1158.01 \\
(63.093)\end{array}$ & $\begin{array}{r}1157.56 \\
(62.085)\end{array}$ & $\begin{array}{r}1155.08 \\
(62.962)\end{array}$ \\
\hline $\begin{array}{l}\text { Full-time Male } \\
\text { Worker (Pf) }\end{array}$ & $\begin{array}{c}0.707 \\
(0.050)\end{array}$ & $\begin{array}{c}0.562 \\
(0.056)\end{array}$ & $\begin{array}{c}0.293 \\
(0.046)\end{array}$ \\
\hline $\begin{array}{l}\text { Part-time Male } \\
\text { Worker (Pp) }\end{array}$ & $\begin{array}{c}0.012 \\
(0.004)\end{array}$ & $\begin{array}{c}0.018 \\
(0.006)\end{array}$ & $\begin{array}{c}0.019 \\
(0.006)\end{array}$ \\
\hline $\begin{array}{l}\text { Unemployed } \\
(\mathrm{Pu})\end{array}$ & $\begin{array}{c}0.070 \\
(0.015)\end{array}$ & $\begin{array}{c}0.043 \\
(0.009)\end{array}$ & $\begin{array}{c}0.013 \\
(0.004)\end{array}$ \\
\hline Ret1red (Pr) & $\begin{array}{c}0.211 \\
(0.040)\end{array}$ & $\begin{array}{c}0.377 \\
(0.055)\end{array}$ & $\begin{array}{c}0.675 \\
(0.049)\end{array}$ \\
\hline $\begin{array}{l}\text { Full-time } \\
\text { Male Wage }\end{array}$ & $\begin{array}{c}0.924 \\
(0.117)\end{array}$ & $\begin{array}{c}0.840 \\
(0.090)\end{array}$ & $\begin{array}{c}0.837 \\
(0.090)\end{array}$ \\
\hline $\begin{array}{l}\text { Part-time } \\
\text { Male Wage }\end{array}$ & $\begin{array}{c}0.571 \\
(0.063)\end{array}$ & $\begin{array}{c}0.623 \\
(0.079)\end{array}$ & $\begin{array}{c}0.624 \\
(0.079)\end{array}$ \\
\hline $\begin{array}{l}\text { Market. } \\
\text { Unemployment }\end{array}$ & $\begin{array}{c}0.027 \\
(0.007)\end{array}$ & $\begin{array}{c}0.027 \\
(0.007)\end{array}$ & $\begin{array}{c}0.027 \\
(0.007)\end{array}$ \\
\hline $\begin{array}{l}\text { No-labor } \\
\text { Income }\end{array}$ & $\begin{array}{r}196.088 \\
(72.843)\end{array}$ & $\begin{array}{r}196.986 \\
(72.877)\end{array}$ & $\begin{array}{r}196.262 \\
(72.203)\end{array}$ \\
\hline $\begin{array}{l}\text { Personal } \\
\text { Savings }\end{array}$ & $\begin{array}{r}1752.95 \\
(319.81)\end{array}$ & $\begin{array}{r}1760.50 \\
(318.33)\end{array}$ & $\begin{array}{r}1765.83 \\
(316.76)\end{array}$ \\
\hline Education & $\begin{array}{c}0.374 \\
(0.094)\end{array}$ & $\begin{array}{c}0.310 \\
(0.081)\end{array}$ & $\begin{array}{c}0.309 \\
(0.080)\end{array}$ \\
\hline $\begin{array}{l}\text { Presence of } \\
\text { Spouse }\end{array}$ & $\begin{array}{c}0.921 \\
(0.015)\end{array}$ & $\begin{array}{c}0.897 \\
(0.033)\end{array}$ & $\begin{array}{c}0.756 \\
(0.015)\end{array}$ \\
\hline
\end{tabular}


Table 3 (concluded)

Statistics

Weighted means and Standard Deviations

\begin{tabular}{lccc}
\hline & \multicolumn{3}{c}{ Means } \\
Variable & $\begin{array}{l}\text { (Standard Deviations) } \\
\text { age group }\end{array}$ & $\begin{array}{l}\text { age group } \\
60-64\end{array}$ & $\begin{array}{c}\text { age group } \\
70 \text { and over }\end{array}$ \\
\hline Famfly & 0.150 & 0.150 & 0.151 \\
Structure & $(0.054)$ & $(0.055)$ & $(0.054)$ \\
Tension & 0.007 & 0.006 & 0.007 \\
& $(0.133)$ & $(0.133)$ & $(0.135)$ \\
Lffe Expectancy & 4.299 & 4.299 & 4.299 \\
& $(0.004)$ & $(0.004)$ & $(0.004)$ \\
\hline
\end{tabular}


Table 4

Empirical Results of Retirement Model: Age 60-64

\begin{tabular}{|c|c|c|c|}
\hline $\begin{array}{l}\text { Independent } \\
\text { variable }\end{array}$ & $\begin{array}{l}\text { le(Pf/Pr) } \\
\text { full-time }\end{array}$ & $\begin{array}{l}\ln (\mathrm{Pp} / \mathrm{Pr}) \\
\text { part-time }\end{array}$ & $\begin{array}{l}\ln (\mathrm{Pu} / \mathrm{Pr}) \\
\text { unemployed }\end{array}$ \\
\hline Intercept & $\begin{array}{l}-15.497 \\
(16.92)\end{array}$ & $\begin{array}{r}43.521 \\
(31.63)\end{array}$ & $\begin{array}{l}-48.037^{* *} \\
(18.72)\end{array}$ \\
\hline SSRB & $\begin{array}{l}-1.567 \mathrm{E}-3 * * * \\
(0.27 \mathrm{E}-3)\end{array}$ & $\begin{array}{l}-1.424 \mathrm{E}-3 * * * \\
(0.50 \mathrm{E}-3)\end{array}$ & $\begin{array}{l}0.718 \mathrm{E}-3 * * \\
(0.30 \mathrm{E}-3)\end{array}$ \\
\hline $\begin{array}{l}\text { Full-time male } \\
\text { wage }(60-64)\end{array}$ & $\begin{array}{l}0.506^{*} \\
(0.29)\end{array}$ & $\begin{array}{l}-0.941^{*} \\
(0.53)\end{array}$ & $\begin{array}{l}0.661 * * \\
(0.34)\end{array}$ \\
\hline $\begin{array}{l}\text { Part-time male } \\
\text { wage }(60-64)\end{array}$ & $\begin{array}{l}-0.844 * * \\
(0.37)\end{array}$ & $\begin{array}{r}0.152 \\
(0.70)\end{array}$ & $\begin{array}{l}-0.705 \\
(0.44)\end{array}$ \\
\hline $\begin{array}{l}\text { Market } \\
\text { Unemployment }\end{array}$ & $\begin{array}{l}-20.473 * * * \\
(2.84)\end{array}$ & $\begin{array}{l}-15.167 * * * \\
(5.30)\end{array}$ & $\begin{array}{l}-0.589 \\
(3.18)\end{array}$ \\
\hline $\begin{array}{l}\text { Non-labor } \\
\text { income }\end{array}$ & $\begin{array}{l}1.61 .9 E-3 * * * \\
(0.57 \mathrm{E}-3)\end{array}$ & $\begin{array}{l}-2.451 \mathrm{E}-3^{* *} \\
(1.08 \mathrm{E}-3)\end{array}$ & $\begin{array}{c}0.180 E-3 \\
(0.63 E-3)\end{array}$ \\
\hline $\begin{array}{l}\text { Personal } \\
\text { savings }\end{array}$ & $\begin{array}{c}0.108 E-3 \\
(0.09 E-3)\end{array}$ & $\begin{array}{l}0.345 \mathrm{E}-3 * * \\
(0.16 \mathrm{E}-3)\end{array}$ & $\begin{array}{l}0.225 E-3 * * \\
(0.10 E-3)\end{array}$ \\
\hline $\begin{array}{l}\text { Education } \\
(60-64)\end{array}$ & $\begin{array}{r}0.191 \\
(0.42)\end{array}$ & $\begin{array}{l}2.089 * * \\
(0.77)\end{array}$ & $\begin{array}{c}-0.404 \\
(0.47)\end{array}$ \\
\hline $\begin{array}{l}\text { Presence of } \\
\text { spouse }(60-64)\end{array}$ & $\begin{array}{l}7.007 * * * \\
(1.45)\end{array}$ & $\begin{array}{l}-2.784 \\
(3.13)\end{array}$ & $\begin{array}{r}-2.453 \\
(1.66)\end{array}$ \\
\hline $\begin{array}{l}\text { Fanily } \\
\text { structure }\end{array}$ & $\begin{array}{l}-1.349 * * \\
(0.63)\end{array}$ & $\begin{array}{l}2.889^{* *} \\
(1.07)\end{array}$ & $\begin{array}{r}-1.219 \\
(0.75)\end{array}$ \\
\hline Tension & $\begin{array}{l}-0.264 * * \\
(0.11)\end{array}$ & $\begin{array}{r}-0.142 \\
(0.19)\end{array}$ & $\begin{array}{l}-0.254^{*} \\
(0.13)\end{array}$ \\
\hline $\begin{array}{l}\text { Life expectancy } \\
\text { (ln) }\end{array}$ & $\begin{array}{l}2.854 \\
(3.92)\end{array}$ & $\begin{array}{l}-9.846 \\
(7.31)\end{array}$ & $\begin{array}{l}11.181 * * \\
(4.34)\end{array}$ \\
\hline $\begin{array}{l}\text { F-statistic } \\
\text { R-squared }\end{array}$ & $\begin{array}{r}28.08 \\
0.90\end{array}$ & $\begin{array}{r}12.19 \\
0.79\end{array}$ & $\begin{array}{r}12.52 \\
0.80\end{array}$ \\
\hline
\end{tabular}

Standard Exrors are in parentheses. Asterisks represent significance levels of logit coefficients as follows: *** 99\% level, ** 95\% level, and * 90\% level for a two-tailed test. A $(\ln )$ next to a variable indicates the natural Jogarithm of the variable. 
Table 5

Empirical Results of Retirement Model: 65-69

\begin{tabular}{|c|c|c|c|}
\hline $\begin{array}{l}\text { Independent } \\
\text { variable }\end{array}$ & $\begin{array}{l}\text { le(Pf } / P r) \\
\text { full-time }\end{array}$ & $\begin{array}{l}\ln (\mathrm{Pp} / \mathrm{Pr}) \\
\text { part-time }\end{array}$ & $\begin{array}{l}\ln (\mathrm{Pu} / \mathrm{Pr}) \\
\text { Unemployed }\end{array}$ \\
\hline Intercept & $\begin{array}{r}-1.103 \\
(18.16)\end{array}$ & $\begin{array}{r}22.217 \\
(32.91)\end{array}$ & $\begin{array}{l}-28.114 \\
(20.91)\end{array}$ \\
\hline SSRB & $\begin{array}{l}-1.354 \mathrm{E}-3^{* * *} \\
(0.32 \mathrm{E}-3)\end{array}$ & $\begin{array}{l}-1.509 \mathrm{E}-3^{* *} \\
(0.57 \mathrm{E}-3)\end{array}$ & $\begin{array}{l}0.640 \mathrm{E}-3^{*} \\
(0.37 \mathrm{E}-3)\end{array}$ \\
\hline $\begin{array}{l}\text { Full-time male } \\
\text { wage ( } 65 \text { and over }\end{array}$ & $\begin{array}{r}-0.285 \\
\mathrm{r})(0.28)\end{array}$ & $\begin{array}{l}-0.151 \\
(0.47)\end{array}$ & $\begin{array}{r}-0.222 \\
(0.36)\end{array}$ \\
\hline $\begin{array}{l}\text { Part-time male } \\
\text { wage ( } 65 \text { and over }\end{array}$ & $\begin{array}{r}-0.218 \\
\text { r) }(0.23)\end{array}$ & $\begin{array}{r}0.282 \\
(0.44)\end{array}$ & $\begin{array}{l}-0.684^{* *} \\
(0.28)\end{array}$ \\
\hline $\begin{array}{l}\text { Market } \\
\text { Unemployment }\end{array}$ & $\begin{array}{l}-16.670 * * * \\
(3.15)\end{array}$ & $\begin{array}{l}-14.032^{* *} \\
(5.84)\end{array}$ & $\begin{array}{r}1.211 \\
(3.72)\end{array}$ \\
\hline $\begin{array}{l}\text { Non-labor } \\
\text { income }\end{array}$ & $\begin{array}{c}0.473 \mathrm{E}-3 \\
(0.56 \mathrm{E}-3)\end{array}$ & $\begin{array}{c}-0.160 \mathrm{E}-2 \\
(0.10 \mathrm{E}-2)\end{array}$ & $\begin{array}{l}1.463 \mathrm{E}-3^{* *} \\
(0.62 \mathrm{E}-3)\end{array}$ \\
\hline $\begin{array}{l}\text { Personal } \\
\text { savings }\end{array}$ & $\begin{array}{l}0.254 \mathrm{E}-3^{* * * *} \\
(0.09 \mathrm{E}-3)\end{array}$ & $\begin{array}{l}0.423 \mathrm{E}-3^{* *} \\
(0.16 \mathrm{E}-3)\end{array}$ & $\begin{array}{l}0.248 \mathrm{E}-3^{* *} \\
(0.11 \mathrm{E}-3)\end{array}$ \\
\hline $\begin{array}{l}\text { Education } \\
\text { ( } 65 \text { and over) }\end{array}$ & $\begin{array}{r}0.832 \\
(0.56)\end{array}$ & $\begin{array}{r}0.224 \\
(1.01)\end{array}$ & $\begin{array}{l}-0.207 \\
(0.66)\end{array}$ \\
\hline $\begin{array}{l}\text { Presence of } \\
\text { spouse }(65-69)\end{array}$ & $\begin{array}{l}3.120 * * * \\
(0.56)\end{array}$ & $\begin{array}{l}3.892 * * * \\
(0.90)\end{array}$ & $\begin{array}{l}2.819^{* * *} \\
(0.65)\end{array}$ \\
\hline $\begin{array}{l}\text { Family } \\
\text { structure }\end{array}$ & $\begin{array}{l}-0.775 \\
(0.65)\end{array}$ & $\begin{array}{l}1.853^{*} \\
(1.09)\end{array}$ & $\begin{array}{l}-2.521 * * * \\
(0.83)\end{array}$ \\
\hline Tension & $\begin{array}{l}-0.236^{*} \\
(0.12)\end{array}$ & $\begin{array}{l}-0.085 \\
(0.20)\end{array}$ & $\begin{array}{l}-0.321 * * \\
(0.15)\end{array}$ \\
\hline $\begin{array}{l}\text { Life expectancy } \\
\text { (ln) }\end{array}$ & $\begin{array}{r}0.097 \\
(4.24)\end{array}$ & $\begin{array}{l}-6.387 \\
(7.69)\end{array}$ & $\begin{array}{r}5.342 \\
(4.89)\end{array}$ \\
\hline $\begin{array}{l}\text { F-statistic } \\
\text { R-squared }\end{array}$ & $\begin{array}{r}22.78 \\
0.88\end{array}$ & $\begin{array}{r}14.16 \\
0.82\end{array}$ & $\begin{array}{r}15.38 \\
0.83\end{array}$ \\
\hline
\end{tabular}

Standard Errors are in parentheses. Asterisks represent significance levels of logit coefficients as follows: *** $99 \%$ level, ** $95 \%$ level, and * 90\% level for a two-tailed test. A $(\ln )$ next to a variable indicates the natural logarithm $f$ the variable. 
Table 6

Empirical Results of Retirement Model: 70 and over

\begin{tabular}{|c|c|c|c|}
\hline $\begin{array}{l}\text { Independent } \\
\text { variable }\end{array}$ & $\begin{array}{l}\text { le(Pf/Pr) } \\
\text { full-tine }\end{array}$ & $\begin{array}{l}\ln (\mathrm{Pp} / \mathrm{Pr}) \\
\text { part-time }\end{array}$ & $\begin{array}{l}\ln (\mathrm{Pu} / \mathrm{Pr}) \\
\text { unemployed }\end{array}$ \\
\hline Intercept & $\begin{array}{l}-37.743^{* *} \\
(16.38)\end{array}$ & $\begin{array}{l}-28.401 \\
(34.33)\end{array}$ & $\begin{array}{l}-30.432 \\
(29.44)\end{array}$ \\
\hline SSRB & $\begin{array}{l}-0.797 E-3^{* *} \\
(0.30 E-3)\end{array}$ & $\begin{array}{c}-0.851 \mathrm{E}-3 \\
(0.62 \mathrm{E}-3)\end{array}$ & $\begin{array}{c}1.017 \mathrm{E}-3^{*} \\
(0.55 \mathrm{E}-3)\end{array}$ \\
\hline $\begin{array}{l}\text { Full-time male } \\
\text { wage ( } 65 \text { and over }\end{array}$ & $\begin{array}{l}-0.609 * * \\
(0.24)\end{array}$ & $\begin{array}{l}-0.613 \\
(0.47)\end{array}$ & $\begin{array}{r}0.017 \\
(0.48)\end{array}$ \\
\hline $\begin{array}{l}\text { Part-time male } \\
\text { wage ( } 65 \text { and over }\end{array}$ & $\begin{array}{r}-0.216 \\
(0.21)\end{array}$ & $\begin{array}{r}0.027 \\
(0.44)\end{array}$ & $\begin{array}{l}-0.755^{*} \\
(0.38)\end{array}$ \\
\hline $\begin{array}{l}\text { Market } \\
\text { Unemployment }\end{array}$ & $\begin{array}{l}-14.630^{* * * *} \\
(2.91)\end{array}$ & $\begin{array}{l}-14.198^{* *} \\
(6.11)\end{array}$ & $\begin{array}{l}-1.367 \\
(5.36)\end{array}$ \\
\hline $\begin{array}{l}\text { Non--Jabor } \\
\text { income }\end{array}$ & $\begin{array}{r}0.297 \mathrm{E}-3 \\
(0.46 \mathrm{E}-3)\end{array}$ & $\begin{array}{l}-2.948 \mathrm{E}-3^{* * * *} \\
(0.95 \mathrm{E}-3)\end{array}$ & $\begin{array}{l}1.413 \mathrm{E}-3^{*} \\
(0.79 \mathrm{E}-3)\end{array}$ \\
\hline $\begin{array}{l}\text { Personal } \\
\text { savings }\end{array}$ & $\begin{array}{l}0.398 \mathrm{E}-3 * * * \\
(0.08 \mathrm{E}-3)\end{array}$ & $\begin{array}{l}0.735 E-3^{* * *} \\
(0.16 E-3)\end{array}$ & $\begin{array}{l}0.534 \mathrm{E}-3^{* * *} \\
(0.14 \mathrm{E}-3)\end{array}$ \\
\hline $\begin{array}{l}\text { Education } \\
\text { (65 and over) }\end{array}$ & $\begin{array}{r}0.210 \\
(0.49)\end{array}$ & $\begin{array}{r}0.888 \\
(0.99)\end{array}$ & $\begin{array}{l}-0.628 \\
(0.93)\end{array}$ \\
\hline $\begin{array}{l}\text { Presence of spo- } \\
\text { use ( } 70 \text { and over) }\end{array}$ & $\begin{array}{l}3.892^{* * *} \\
(1.16)\end{array}$ & $\begin{array}{l}-3.126 \\
(2.48)\end{array}$ & $\begin{array}{r}0.087 \\
(2.02)\end{array}$ \\
\hline $\begin{array}{l}\text { Family } \\
\text { structure }\end{array}$ & $\begin{array}{r}-0.931 \\
(0.59)\end{array}$ & $\begin{array}{r}1.682 \\
(1.14)\end{array}$ & $\begin{array}{l}-4.633^{* * *} \\
(1.21)\end{array}$ \\
\hline Tension & $\begin{array}{l}-0.176^{*} \\
(0.10)\end{array}$ & $\begin{array}{l}-0.010 \\
(0.19)\end{array}$ & $\begin{array}{l}-0.407 * * \\
(0.19)\end{array}$ \\
\hline $\begin{array}{l}\text { Life expectancy } \\
(\ln )\end{array}$ & $\begin{array}{l}8.194^{* *} \\
(3.84)\end{array}$ & $\begin{array}{r}6.461 \\
(8.40)\end{array}$ & $\begin{array}{r}5.908 \\
(6.91)\end{array}$ \\
\hline $\begin{array}{l}\text { F-statistic } \\
\text { R-scquared }\end{array}$ & $\begin{array}{r}27.03 \\
0.90\end{array}$ & $\begin{array}{r}12.05 \\
0.79\end{array}$ & $\begin{array}{r}23.17 \\
0.88\end{array}$ \\
\hline
\end{tabular}

Standard Errors are in parentheses. Asterisks represent significance levels of logit coefficients as follows: *** $99 \%$ level, ** 95\% level, and * $90 \%$ level for a two-tailed test. A (ln) next to a variable indicates the natural logarithm of the variable. 


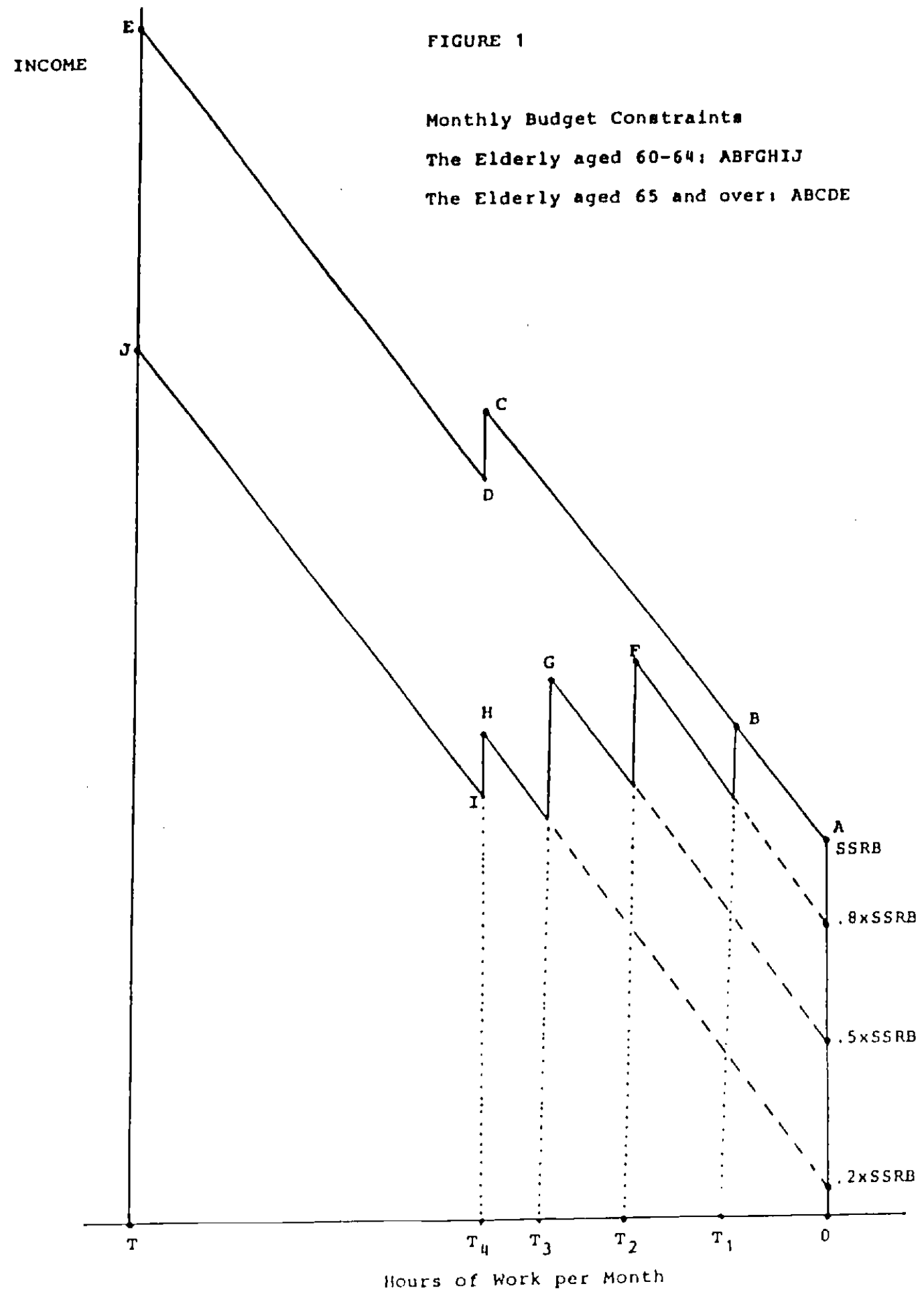




\section{REFERENCES}

Blinder, Alan S., Gordon, Roger H., and Wise, Donald E., "Reconsidering the Work Disincentive Effects of Social Security." National Tax Journal 33 (December 1980): 431-42.

Boskin, Michael, "Social Security and Retirement Decisions." Economic Inquiry 15 (January 1977): 1-23.

Burtless, Gary, and Moffitt, Robert A., "Social Security, Earnings Tests, and Age at Retirement." Public Finance Quarterly 14 (January 1986): 3-27.

, and Moffitt, Robert A., "The Joint Choice of Retirement Age and Postretirement Hours of Work." Journal of Labor Economics 3 (April 1985): 209-36.

Cropper, M.L., "Measuring the Benefits from Reduced Morbidity." American Economic Review 71 (May 1981): 235-40.

Duggan, James E., "The Labor-Force Participation of older Worker." Industrial and Labor $\underline{\text { Relations }}$ Review 37 (April 1984): 416-30.

Fuchs, Victor R., "Though Much is Taken--Reflections on Aging, Health, and Medical Care." Working Paper no.1269. Cambridge, Mass.: NBER, January 1984.

Gerking, Shelby and Schulze, William, "What Do We Know about Benefits of Reduced Mortality from Air Pollution Control ?" American Economic Review 71 (May 1981): 228-34.

Gustman, Alan L., and Steinmeier, Thomas L,, "Retirement Flows." Working Paper no.1069. Cambridge, Mass.: NBER, January 1983.

, and Steinmeier, Thomas L., "Partial Retirement and the Analysis of Retirement Behavior." Industrial and Labor Relations Review 37 (April 1984): 403-15.

Hamermesh, Daniel, "Life-Cyle Effects on Consumption and Retirement." Journal of Labor Economics 2 (July 1984): 353-70.

Hanoch, Giora and Honig, Marjorie, "Retirement, Wages, and and Labor Supply of the Elderly." Journal of Labor Economics 1 (April 1983): 131-51.

Honig, Marjorie and Hanoch, Giora, "Partial Retirenent as a Separate Mode of Retirement Behavior." Journal of Human Resources 20 (Winter 1985): $21-46$.

Hurd, Michael D., and Boskin, Michael J., "The Effect of Social Security on Retirement in the Early 1970s," Quarterly Journal of Economics 99 (November 1984 ): $767-90$.

Ito, Minoru, "Koreisha no Kyushoku Kodo to Nenkin Koyo Hoken," (in Japanese), Nippon Rodo Kyokai Zashi 288 (March/April 1983): 12-23.

Japan, Asahi Shinbun Sha, Minryoku 1982 and 1983 (in Japanese), Tokyo, 1982 and 1983 . 
Tokyo, 1981 .

, Department of Labor, Wage Census, Showa 55 Nenban (in Japanese), - Department of Labor, White Paper of Labor, Showa 58 Nenban (in Japanese), Tokyo, 1983 .

1982 .

, Department of Labor, Year Book of Labor Statistics 1982, Tokyo,

, Office of the Prime Minister, Bureau of Statistics, 1980 Population Census of Japan, Tokyo, 1983.

, Statistics Bureau Prime Minister's office, Annual Report on the Family Income and Expenditure Survey 1980, Tokyo, 1981.

- Statistics Bureau Prime Minister's office, Japan Statistical Yearbook 1982, Tokyo, 1982 .

Mitchell, olivia S. and Fields, Gary S., "The Economics of Retirement Behavior," Journal of Labor Economics 2 (January 1984): 84-105.

Pellechio, Anthony, "Social Security Financing and Retirement Behavior," American Economic Review 69 (May 1979): 284-7.

Rones, Philip L., "The Retirement Decision: A Question of Opportunity ?" Monthly Labor Review 103 (November 1980): $14-7$.

Rosen, Sherwin, "Valuing Health Risk," American Economic Review 71 (May 1981): 241-45.

Takayama, Noriyuki, "Japan," In The World Crisis in Social Security, edited by Jean-Jacques Rosa. Paris, Fondation National d'Economie Politique, 1982.

Wolfe, Barbara L., "Measuring Disability and Health," Journalof Health Economics 3 (August 1984): 187-93. 
</ref_section> 